\title{
Annual volume increment of the European forests - description and evaluation of the national methods used
}

\author{
Stein Michael Tomter ${ }^{1}$ • Andrius Kuliešis ${ }^{2}$ • Thomas Gschwantner ${ }^{3}$
}

Received: 5 May 2015 / Accepted: 12 May 2016/Published online: 13 June 2016

(C) INRA and Springer-Verlag France 2016

\begin{abstract}
- Key message In order to obtain the necessary information for decision making etc., it is of increasing importance to be able to assess increment in a reliable way. Only repeated measurements on permanent sample plots in national forest inventories can provide accurate and comprehensive information on the various components of annual increment. Such inventory systems are increasingly employed in European countries. The felling/increment ratio, characterizing wood use sustainability, should be expressed as the ratio of felled living trees (excluding dead trees) and net increment.

- Context Reporting of gross and net annual increment is an element of international forest resource assessments and crucial for sustainable forest management. A number of approaches exist for the estimation of increment and its various sub-components.
\end{abstract}

Handling Editor: Jean-Michel Leban

Contribution of the co-authors Stein Michael Tomter: coordination, ToS of SFM questionnaire design, data analysis, and writing of manuscript

Andrius Kuliešis: ToS of SFM questionnaire design, data analysis, and writing of manuscript

Thomas Gschwantner: analysis of results and writing of manuscript

Stein Michael Tomter

stein.tomter@nibio.no; stemtomt@gmail.com

1 Norwegian Institute of Bioeconomy Research, P.O. Box 115, N-1431 Ås, Norway

2 Lithuanian State Forest Service, Pramones av. 11a, 51327 Kaunas, Lithuania

3 Austrian Research Centre for Forests, Seckendorff-Gudent-Weg 8, 1131 Vienna, Austria
- Aims The main objectives of the study are to assess in detail what methods European countries have used and are planning to use in the future for international reporting of increment. Also, the usefulness of the various approaches for the assessment of increment is evaluated.

- Methods A questionnaire asking about their assessment methods was distributed among the UNECE/FAO national correspondents of all European countries and members of the UNECE/FAO Team of Specialists on Monitoring Sustainable Forest Management. Databases of the Temperate and Boreal Forest Resource Assessment 2000 and of the State of Europe's Forests 2011 were also used. Furthermore, the methodological background was described on the basis of relevant literature sources and some examples for country groups presented.

- Results Countries have indicated what methods they used for assessment of various increment components, and the percentage of countries, forest area, and growing stock corresponding to these replies has been calculated. With regard to gross annual increment, these metrics represent about one third for inventories based on permanent sample plots, but this percentage is on the increase.

- Conclusion The concept of the "control method" for forest management was developed more than 100 years ago but only utilized at the local level. The same methodology is now widely used at the national and regional level due to the implementation of modern national forest inventories using permanent sample plots. Care should be taken to utilize the data correctly for international forest resource assessments, in order to, e.g., avoid double counting of dead trees.

Keywords Forest inventory $\cdot$ Control method $\cdot$ Forest resources assessment $\cdot$ Annual increment 


\section{Introduction}

The idea of forest management control by assessment of gross increment and its components was born at the end of the nineteenth and the beginning of the twentieth century (Gurnaud 1878; Tiurmer 1891; Biolley 1921). Realization of forest management control and practical solutions for implementation of these ideas were under continuous discussion for a long time. Due to several reasons, these methods could only be partly implemented. One major concern was a lack of efficient methods for the assessment of forest growth and its components. Also, at that time, it did not seem very important to increase forest production. Gross annual increment (GAI) can be regarded as composed of change in growing stock, fellings, and natural losses. The demand of forest products, forest services, and many other forest functions influencing forest productivity has increased substantially. Forest management control is especially important for today's forestry with intensive silvicultural activities. It has been predicted that if no major policies or strategies are changed in the forest sector, consumption of forest products and wood energy will grow steadily, at least until 2030, and wood supply will expand to meet this demand (UNECE/FAO 2011).

Reliable data on forest productivity are required not only on the local and national but also on the international level (UNECE/FAO 2000; FOREST EUROPE, UNECE and FAO 2011). The productivity of forests and components of gross increment in forests of all European countries, using more or less harmonized definitions, were for the first time assessed during Temperate and Boreal Forest Resource Assessment 2000 (TBFRA 2000). Very important for these results is how to combine and compare the data from various inventories at a given date and during a given period. The ratio between fellings and net annual increment (NAI) during the last assessment of European forests was used for evaluation of wood utilization level (FOREST EUROPE, UNECE and FAO 2011), as well as for assessing sustainability of forest management. Net increment differs from gross increment by the amount of tree stem volume that has died naturally between two successive inventories. Assessing net increment only in the evaluation of sustainable forest management means that mortality is accepted as something stable and unchangeable. In fact, the share of trees dying over a certain period of time depends on many factors related to both nature and human impact, such as climate conditions, site, reforestation method, silvicultural measures, etc. (Oliver and Larson 1996; Pretzsch 2009) and varies from country to country. Thus, the mortality rate will also to some extent be related to sustainable forest management. Reliable regular statistical information on gross annual increment and its components is regularly presented only by a few countries, having data from long-term national forest inventories (USDA Forest
Service 2001; USDA Forest Service 2009). Only a part of gross increment in even-aged stands which is accumulated in the stand reaches the age of maturity (Kuliešis 1989; Pretzsch 2009; USDA Forest Service 2001, USDA Forest Service 2009). Another part of the gross increment comprises intermediate use of wood, as thinnings and natural losses. Natural losses were defined as "average annual losses to the growing stock during the given reference period, measured to a minimum diameter of $0 \mathrm{~cm}(\mathrm{dbh})$, due to mortality from causes other than cutting by man, e.g., natural mortality, diseases, insect attacks, fire, windthrow or other physical damage" (UNECE/FAO 2000). Natural losses represent a significant reserve for fuelwood use, maintenance and enhancement of biodiversity, and accumulation of carbon in forests. The ratio between intermediate use and natural losses depends on the intensity of forest management (Kuliešis 1989). It is of increasing importance to have reliable methods for assessing gross increment and its components, in order to achieve the necessary information for practical and political decision making.

The goal of this study is to assess methods for the estimation of gross increment and its components in Europe, including practical abilities of countries to estimate gross increment and its components and to utilize them for forest management in a sustainable way.

The main tasks of the study are the following:

- To assess in detail what methods various European countries have used and are planning to use in the future for international reporting of gross annual increment.

- To evaluate the usefulness of the various assessment methods for gross increment and its components.

\section{Material and methods}

For studying the assessment methods of gross increment in countries, a questionnaire was distributed among the UNECE/ FAO national correspondents of all European countries and members of the UNECE/FAO Team of Specialists on Monitoring Sustainable Forest Management. These are national experts, responsible for, or involved in the process of reporting forest information to international forest resources assessments. Additionally, databases of Temperate and Boreal Forest Resources Assessment (UNECE/FAO 2000) and State of Europe's Forests (SoEF) 2011 (FOREST EUROPE, UNECE and FAO 2011) were used. The questionnaire consisted of 32 questions about the possibilities and methods for the estimation of gross annual increment, natural losses, net annual increment and fellings, as well as the minimum threshold of trees included in estimates. Only the replies 
to a selection of these questions were used for this study. National correspondents were asked, among others, to reply to the following questions:

- What method is used in your country for estimation of gross annual increment and its balance during SoEF 2011 ?

- What method are you planning to use in your country for estimation of gross annual increment and its components in the future assessments?

- What minimum diameter threshold do you use in your country, when estimating gross annual increment and its components?

- Do you have the possibility to estimate gross increment and its components by expert judgment or rough estimation?

Correspondents were asked about five standardized methods for estimation of GAI they currently were using or were planning to use for future assessments (Table 1). These were

1. Summing of estimated volume changes of individual trees directly on permanent plots,

2. Using semi-direct method - diameter increment borings of surviving trees on temporary plots,

3. Summing of gross increment components, measured during successive inventories on permanent plots,

4. Estimation by models, yield tables,

5. Using default values (e.g., fixed percentage of growing stock)

Answers were received from the representatives of 31 European countries, including Russian Federation. The questions of our enquiry were also kindly answered by experts from the USA. Forest area and growing stock of the 30 responding European countries (excluding Russian Federation) corresponded to 186 million ha and 29,288 million $\mathrm{m}^{3}$ or 88.3 and $89.6 \%$ of the total European forest area and growing stock.

The definitions of gross and net annual increment have generally remained the same over the years, but there may be some minor differences. GAI according to the TBFRA 2000 definition was "average annual volume of increment over the reference period of all trees, measured to a minimum diameter at breast height $(\mathrm{dbh})$ of 0 centimetres $(\mathrm{cm})$ " (UNECE/FAO 2000). NAI according to the definition of the TBFRA 2000 was "average annual volume over the given reference period of gross increment less that of natural losses on all trees to a minimum diameter of $0 \mathrm{~cm}$ (dbh)" (UNECE/FAO 2000). Natural losses were defined as "average annual losses to the growing stock during the given reference period, measured to a minimum diameter of $0 \mathrm{~cm}(\mathrm{dbh})$, due to mortality from causes other than cutting by man, e.g., natural mortality, diseases, insect attacks, fire, windthrow or other physical damage."

The corresponding definitions specified for SoEF 2011 were very similar but made more flexible with regard to minimum size of the trees included (FOREST EUROPE, UNECE and FAO 2010). The trees included in the reporting on increment and losses should have the same minimum sizes as defined for growing stock. Countries should indicate minimum dbh, minimum top diameter, and minimum diameter of branches included. Besides, it should be specified whether the reported figures referred to volume above ground or above stump.

GAI can be differentiated into three main components: (1) volume accumulated in tree stems during the assessment period including ingrowth of new trees; (2) volume of trees that have died during the same period, usually referred to as natural losses or mortality; and (3) volume of living trees that have been felled during the period. A part of natural losses is normally also felled and utilized for various purposes but should be kept separate from fellings of living trees for estimation of these components. Net increment can be calculated from gross increment by subtracting the volume of trees that have died naturally during the assessment period. This concept is in principle valid at all levels, from national to stand level.

Table 1 Methods of gross increment estimation used for SoEF 2011 reporting and planning to use in future reporting (in brackets)

\begin{tabular}{|c|c|c|c|}
\hline Methods & Number of countries, $\%$ & Forest area, $\%$ & Growing stock, $\%$ \\
\hline \multicolumn{4}{|l|}{ Summing of current increment (volume changes) of individual trees } \\
\hline - Measured on permanent plots during successive inventories & $33(47)$ & $33(39)$ & $35(42)$ \\
\hline - Measured on temporary plots using increment borings & $30(23)$ & $53(45)$ & $41(34)$ \\
\hline $\begin{array}{l}\text { Summing of gross increment components - growing stock change, } \\
\text { fellings and natural losses, estimated during successive inventories }\end{array}$ & $3(13)$ & $1(11)$ & $2(15)$ \\
\hline Estimated by models, yield tables & $10(13)$ & $6(5)$ & $7(6)$ \\
\hline Default value (fixed percentage of growing stock) & $3(3)$ & $2(2)$ & $2(2)$ \\
\hline Other & $20(13)$ & $33(31)$ & $25(24)$ \\
\hline
\end{tabular}

Data from the questionnaire answered by UNECE/FAO national correspondents and members of the Team of Specialists on Monitoring SFM, from 30 responding countries 
Trees that are present in the stand at the initial inventory will have three possibilities: to continue their growth, to be felled during thinnings or other forest operations, or to die due to, e.g., competition, damages of insects, diseases, or physical factors. All trees, assessed in a stand during the initial inventory at the time $A-n$, can be differentiated into three groups:

$l$ trees that will survive for $n$ years up to the next inventory at the time $(A)$ and their initial volume $n$ years ago

$m_{A-n}=\sum_{i=1}^{l} V_{A-n i}$

$k-l$ trees will be felled during the period of $n$ years and their volume $n$ years ago

$M_{K}=\sum_{i=l+1}^{k} V_{A-n i}$

$t-k$ trees that will die during the period of $n$ years and their volume $n$ years ago

$M_{O}=\sum_{i=k+1}^{t} V_{A-n i}$

Then, the volume of living trees present in the stand $n$ years ago

$M_{A-n}=m_{A-n}+M_{K}+M_{O}$

and at the moment of remeasurement in the next successive inventory

$M_{A}=\sum_{i=1}^{l} V_{A i}$

Volume of gross increment of surviving, felled, and dead trees during a reference period of $n$ years:

$$
\begin{aligned}
Z_{M} & =\sum_{i=1}^{l} V_{A i}-\sum_{i=1}^{l} V_{A-n i}=M_{A}-m_{A-n}+Z_{M K}+Z_{M O} \\
& =M_{A}-M_{A-n}+M_{K}+M_{O}+Z_{M K}+Z_{M O}
\end{aligned}
$$

where $Z_{M K}$ is increment of felled trees and $Z_{M O}$ is increment of dead trees.

Volume change in the stand during the reference period is indicated by $\Delta=M_{\mathrm{A}}-M_{\mathrm{A}-\mathrm{n}}+M_{\mathrm{I}}$, where $M_{\mathrm{I}}$ is the volume of ingrowth, i.e., trees that have passed the minimum threshold for measurement between two inventories. Finally, the increment is equal to the sum of volume change, volume of felled trees, and volume of dead trees during the assessment period, including increment of dead and felled trees before they died or have been felled

$Z_{M}=\Delta+M_{K}+M_{O}+Z_{M K}+Z_{M O}$

Following the TBFRA 2000 definition, volume of all dead trees is equal to volume of natural losses (Eq. 3), and then, net increment can be expressed as

$$
N A I=Z_{M}-M_{0}=\Delta+M_{K}+Z_{M K}
$$

Gross annual increment consists of three main components: volume of stem wood accumulated in the stand, volume of removed trees, and volume of trees that have died:

$G A I=\Delta+M_{K 1}+M_{K 2}+M_{O K}+M_{O O}$

where $\Delta$ is growing stock change, $M_{\mathrm{K} 1}$ is volume of final fellings of living trees, $M_{\mathrm{K} 2}$ is volume of thinnings or other fellings of living trees, $M_{\mathrm{OK}}$ is fellings of dead trees, including harvested natural losses, and $M_{\mathrm{OO}}$ is not harvested natural losses.

Observations on permanent research plots (Pretzsch 2009; Kuliešis et al. 2010) and studies of numerous growth models and yield tables (Kuliešis 1993) show that $50-70 \%$ of total increment in a stand can on average be accumulated and used for final fellings (Fig. 1). Depending on the thinning intensity, the proportion of GAI components changes. A higher share of thinning in GAI reduces the potential natural losses.

Using a theoretical approach, it can be said that the rest of increment represents volume of potential natural losses or potential thinnings, depending on forest management intensity and thinning regime. Increasing the intensity of thinnings up to $30-40 \%$ of the total yield stimulates the accumulation of increment in the stand and the harvested part of the yield, as well as decreases natural losses down to 5-10\%. Potential natural losses during the rotation period of even-aged stands decrease from 40 to $45 \%$ to $5-10 \%$, when the intensity of thinning has been increased from 5 to $35 \%$ of gross increment.

\section{Results}

\subsection{Methods of gross increment estimation}

Twenty countries out of 30 have presented data on gross annual increment for SoEF 2011 (Table 1). Some countries replied that they used in parallel more than one method for GAI estimation. Ten countries (33\%) used data from permanent plots, nine countries (30\%) used increment boring on temporary plots, and one country ( $3 \%$ ) used summing of GAI components. Three countries $(10 \%)$ have been using models together with growing stock figures obtained from standwise inventory (Croatia, Hungary, Romania) or NFI by sampling method. Two countries did not yet finish NFI and used special studies (Ireland) for GAI estimation or used models and growing stock obtained by some other method. Some countries (e.g., Ukraine) have been estimating growing stock changes, i.e., one component of GAI only. Looking at future-planned reporting, $13 \%$ of countries are optimistic on their possibility to utilize data from the NFI, which is in the finishing stage. The two last columns of Table 1 show, respectively, the percentage of forest area and growing stock in Europe that corresponds to the responding countries. 
Fig. 1 Theoretical approach of gross increment balance depending on the intensity of thinning. The proportions of the GAI components are dependent of the thinning intensity. ( $\Delta$ is growing stock change; $M_{K I}$ is volume of final fellings of living trees; $M_{K 2}$ is volume of thinnings or other fellings of living trees; $M_{O K}$ is fellings of dead trees, including harvested natural losses; $M_{O O}$ is not harvested natural losses)

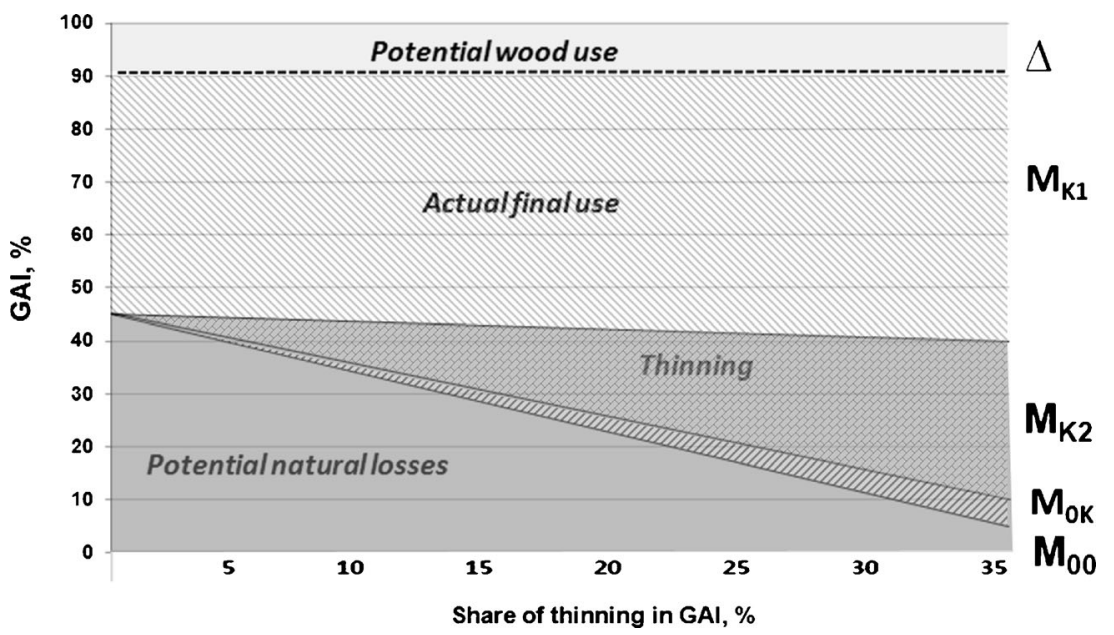

\subsection{Methods of net increment estimation}

Three main methods can be used for net increment estimation (Table 2):

1. The difference between gross increment and natural losses,

2. The sum of growing stock change and fellings,

3. Using models and/or yield tables.

Eight countries (27\%) used method (1) for estimation of NAI, which is in accordance with Eq. (1) to Eq. (8).

Five countries (17\%) used the second method, where NAI was estimated as the sum of growing stock change and volume of fellings. Only two countries $(7 \%)$ used models and yield tables. The reliability of the result obtained by the last mentioned, as well as by the other methods used by four countries (13\%), cannot be controlled by the components of GAI. Among the other methods, a procedure based on extrapolation of data from the past was reported, as well as estimation of the mean value for the assessment period, accepting the sum of mean annual growing stock change per age class as net increment. The reliability of the presented results by these methods should be evaluated using objectively obtained data in the future based on the first and second methods (Table 2).
For future NAI assessment, six new countries are planning to use measurements on permanent plots, while seven countries are considering the sum of growing stock changes and felling estimates. One country is planning to use models or yield tables.

\subsection{Methods of natural loss estimation}

Three main methods can be used for estimation of natural losses (Table 3). Natural losses are due to mortality and can be derived as the difference between GAI and NAI. It is a significant component of the GAI balance and an important parameter, characterizing the level of GAI utilization, as well as the efficiency of forestry. Nevertheless, the attention of countries toward the reporting of this parameter has been limited. Only 10 countries out of 30 have reported data on natural losses for SoEF 2011. Five countries used direct measurements on permanent plots (out of 10 possible) as the main method, while one country applied default values and five used other methods. These other methods comprised estimation based on expert opinion (UK), summary of data from forest management plans, and use of data from case studies. It is possible that reporting on natural losses can be doubled in future assessments. Seven new countries are planning to use

Table 2 Methods of net increment estimation used for SoEF 2011 reporting and planning to use in future reporting (in brackets)

\begin{tabular}{|c|c|c|c|}
\hline Methods & Number of countries, $\%$ & Forest area, $\%$ & Growing stock, \% \\
\hline $\begin{array}{l}\text { Estimated as the difference between gross increment and natural losses, } \\
\text { measured over the period between two successive inventories }\end{array}$ & $27(47)$ & $45(57)$ & $38(53)$ \\
\hline $\begin{array}{l}\text { Estimated as the sum of growing stock change and fellings, measured } \\
\text { over the period between two successive inventories }\end{array}$ & $17(40)$ & $20(35)$ & $16(34)$ \\
\hline Estimated by models, yield tables & $7(10)$ & $2(4)$ & $3(4)$ \\
\hline Other & $13(3)$ & $2(2)$ & $3(1)$ \\
\hline
\end{tabular}

Data from the questionnaire answered by UNECE/FAO national correspondents and members of the Team of Specialists on Monitoring SFM, from 30 responding countries 
Table 3 Methods of natural loss estimation used for SoEF 2011 reporting and planning to use in future reporting (in brackets)

\begin{tabular}{llll}
\hline Methods & Number of countries, $\%$ & Forest area, \% & Growing stock, \% \\
\hline $\begin{array}{l}\text { Assessment on permanent plots, as the volume of dead trees } \\
\quad \text { between two successive inventories }\end{array}$ & $17(40)$ & $16(34)$ & $15(33)$ \\
$\begin{array}{l}\text { Estimation by models, yield tables } \\
\text { Estimation by default values, possibly based on case studies }\end{array}$ & $0(7)$ & $0(6)$ & $0(9)$ \\
Other & $17(23)$ & $6(0)$ & $3(0)$ \\
\hline
\end{tabular}

Data from the questionnaire answered by UNECE/FAO national correspondents and members of the Team of Specialists on Monitoring SFM, from 30 responding countries

measurements on permanent plots for future assessments, while two are planning to apply models and yield tables.

\subsection{Methods of felling estimation}

Three main methods were used for estimation of fellings (Table 4):

1. Inventory of stumps in successive surveys on permanent plots

2. Measurements of stumps on temporary plots

3. Using statistics of timber harvest

Only five countries have used measurements of stumps on permanent plots, while two countries used data from temporary plots. One of these combined data from permanent and temporary plots. Statistics of removals were used as the main method by 19 countries for reporting of fellings. Four countries used various other methods: special studies, harvest records, forest management plans, and reports from forest managers. Countries are planning to increase measurements on permanent plots more than twice for future assessments of fellings. Some countries are planning to combine statistics of removals with data from inventory, especially permanent plots.

\subsection{Gross annual increment and its components}

To verify the theoretical approach described in the "Material and methods" section (Fig. 1), data on natural losses reported for
TBFRA 2000 and SoEF 2011 (UNECE/FAO 2000; FOREST EUROPE, UNECE and FAO 2011) were compiled for countries with an NFI based on permanent plots, characterized by a different potential growth in the three country groups (Fig. 2).

The mean gross increment in all countries has increased during the period $2000-2010$ by on average $1-2 \mathrm{~m}^{3} / \mathrm{ha}$. The share of gross increment accumulated in the stand changes during 2000-2010 from 27 to $28 \%$ in countries of group 2, up to $38-45 \%$ in countries of groups 4 and 6 . The largest part of increment (67-68\%) was felled during final felling and thinning by countries of group 2 . That implies a low share of $5 \%$ natural losses, from which $30 \%$ on average is harvested and removed from the forest. Fellings represent $31-39 \%$ of the total increment in forests of group 4, which is the lowest share compared with countries of groups 2 and 6 . Countries of group 4 are characterized by the highest share of natural losses, of which only $20 \%$ on average is harvested.

\section{Discussion}

Only data obtained from permanent plots permit reporting on the complete increment balance and management control. GAI estimated by increment boring on temporary plots is usually accurate enough for many purposes; nevertheless, measurements on temporary plots are limited for detecting the structure of GAI, including volume of felled and of dead trees. The low accuracy of estimation of these characteristics depends on difficulties in assessing the time when felling or
Table 4 Methods of felling estimation used for SoEF 2011 reporting and planning to use in future reporting (in brackets)

\begin{tabular}{llll}
\hline Methods & $\begin{array}{l}\text { Number of } \\
\text { countries, } \%\end{array}$ & Forest area, \% & $\begin{array}{l}\text { Growing } \\
\text { stock, \% }\end{array}$ \\
\hline Successive inventories on permanent plots & $17(47)$ & $12(27)$ & $21(28)$ \\
Measurements of stumps on temporary plots & $7(7)$ & $2(2)$ & $3(3)$ \\
Statistics of timber harvest & $63(43)$ & $59(46)$ & $56(33)$ \\
- of which with a procedure to adjust for harvesting losses & 27 & 49 & 39 \\
Other & $13(10)$ & $22(22)$ & $17(17)$ \\
\hline
\end{tabular}

Data from the questionnaire answered by UNECE/FAO national correspondents and members of the Team of Specialists on Monitoring SFM, from 30 responding countries 


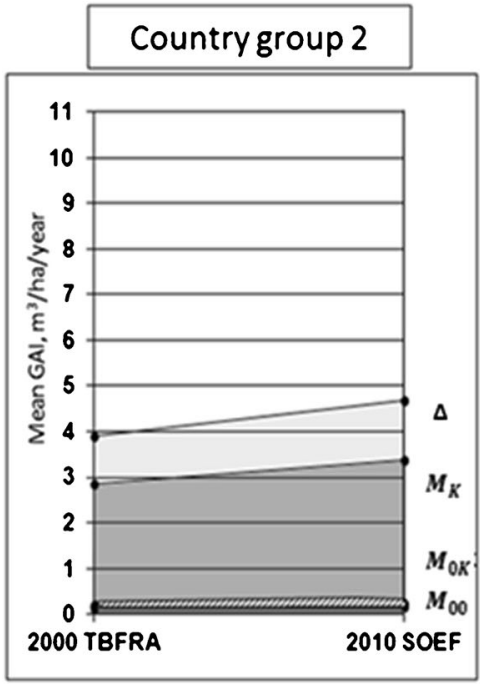

Fig. 2 Comparison of gross annual increment balance on forest available for wood supply in different groups of European countries according to TBFRA 2000 and SoEF 2011 data (Norway, Sweden, Finland, Ireland (group 2); Estonia, Latvia, Lithuania, Belarus, Denmark (group 4);
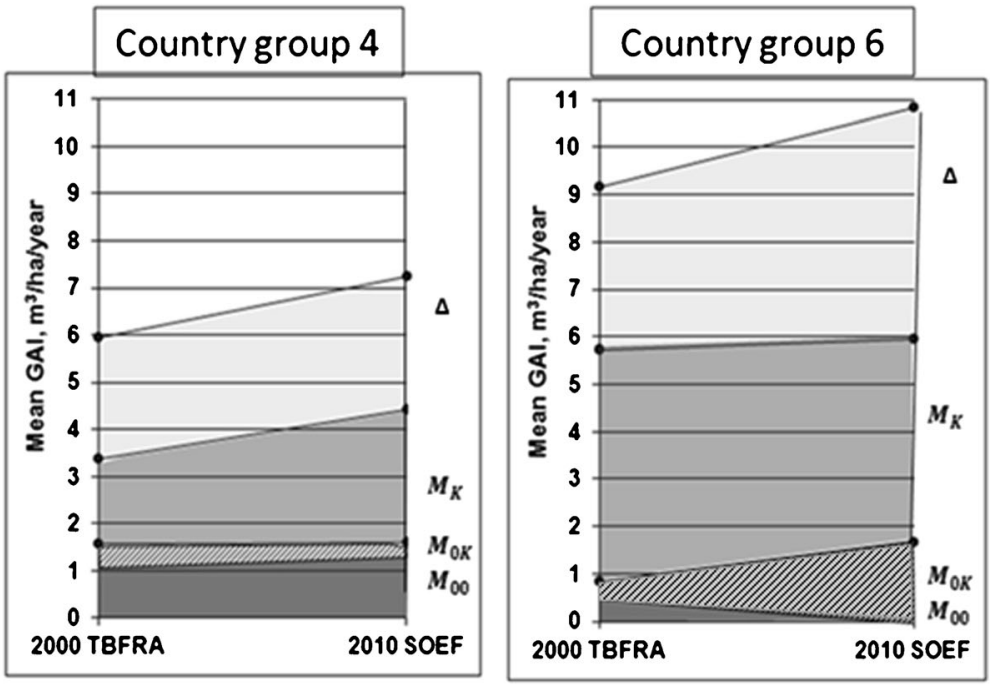

Germany, Switzerland, Austria, Czech Republic, Slovenia, Liechtenstein (group 6)) ( $\Delta$ is growing stock change; $M_{K}$ is volume of fellings of living trees; $M_{O K}$ is fellings of dead trees, including harvested natural losses; $M_{O O}$ is not harvested natural losses)

death of a tree occurred (Zöhrer 1980). Many countries understood this situation and have already implemented or are in the nearest future ready to give emphasis to measurements on permanent plots. Some countries (Estonia, Latvia, Netherlands, and UK) are finishing their NFI and are expecting to improve the accuracy of GAI estimates. The accuracy of GAI estimation using other methods, as models, yield tables, and default values, depends on the accuracy of growing stock estimates, objectivity, and quality of information on felling and dead trees.

Although the results from our enquiry may be not completely without errors and uncertainties, it is quite obvious that several countries are planning to introduce repeated measurements on permanent sample plots as the basis for future international reporting (Tables 1-4).

Following the ideas of forest management control (Gurnaud 1878; Tiurmer 1891; Biolley 1921), the components of gross annual increment have become a cornerstone of forest management today. Optimal wood production together with non-wood goods, biodiversity, and carbon sequestration can be achieved under permanent control of growth and distribution of growth into different components. Dead trees can be left in forest for decomposition, enhancement of biodiversity, or be removed from the forest. In the first case, dead trees represent a reduction of forest production. When dead trees are removed from the forest, natural losses can be utilized and the efficiency of forest management increased.

The most reliable system for GAI and assessment of its components would be direct measurements of the growth on permanent plots. It is a source of objective information, and all conclusions about forest growth and its use should be based on this information. The other sources of information, like data from wood industry, wood markets, statistics of removals, information from forest managers, and harvest records can be used for estimation of rationality of forest growth and logging, as well as for specification of annual statistics of GAI and its components.

In our set of Eqs. (1-8), felled trees can only be recorded from those previously assessed as living trees. Dead trees can only be assessed as felled from the category of trees, classified in the previous inventory as dead. It means that during assessments, it is very important to separate felling of dead trees from felling of living trees. The ratio of felled living trees and net annual increment, not containing dead trees, is the real indicator of wood utilization intensity and sustainability. Felling of dead trees will decrease the volume of natural losses left in the forest. The amount of natural losses is an indicator of the efficiency of forest management. These circumstances indicate that the definition of annual fellings as "average annual standing volume of all trees, living or dead, measured over bark to a minimum diameter $0 \mathrm{~cm}$ that are felled during the given reference period, including the volume of trees or parts of trees that are not removed from the forest, other wooded land or other felling site" (UNECE/FAO 2000) should be further differentiated. The application of models or default values, e.g., as included in the Joint FOREST EUROPE/UNECE/FAO questionnaire on pan-European indicators for sustainable forest management (FOREST EUROPE, UNECE, FAO 2013), is an option to improve international reporting when adequate inventory data are not available. The background for these methods is described in Kuliešis et al. (2016).

In case the volume of dead and felled trees between two inventories were estimated from the results of the primary inventory, the increment $\left(Z_{M O}, Z_{M K}\right)$ between the first inventory and the moment of death or felling of the tree will not be 
accounted for. The increment of dead $\left(Z_{M O}\right)$ or felled $\left(Z_{M K}\right)$ trees can be assessed by taking additional measurement or by modeling. Its size usually represents about $2-3 \%$ of total gross increment (Antanaitis and Zagreev 1981) and is usually not an important component. It means that for practical purposes, the increment of felled and dead trees in Eq. 6-8 may be omitted.

\section{Conclusions}

1. The ideas of sustainable forest management control, based on gross increment and monitoring of its components, becomes a reality today due to the wide implementation of national forest inventories in Europe, based on permanent sample plots.

2. Net increment does not include natural losses (mortality). To avoid double counting of dead trees, the felling/ increment ratio, characterizing wood use sustainability, should be expressed as the ratio of felled living trees and net increment.

3. Mortality, varying from 5 to $27 \%$ of gross increment in European forests, depends on the intensity of thinning and serves as an indicator of intensity of forest management.

Acknowledgments This study has been developed in the framework of the COST Action FP1001. (USEWOOD: Improving Data and Information on the Potential Supply of Wood Resources: A European Approach from Multisource National Forest Inventories). We wish to thank all the members of Working Group 1 "Assessment and estimation techniques of state and changes in wood resources" for valuable discussions during the meetings, national correspondents for answering the Questionnaire on Pan-European Indicators for Sustainable Forest Management and giving valuable information on development of national forest inventory capacities in their countries, and R. Michalak, Forestry and Timber Section, UNECE for supporting the idea of distributing a questionnaire among the national correspondents.

Funding This research was supported by the Cost Action FP1001.

\section{References}

Антанайтис ВВ, Загреев ВВ (1981) Прирост леса. Москва, изд. Лесная промышленность (in Russian) Antanaitis VV, Zagreev VV (1981) Forest increment. Moscow. Lesnaja promyšlennost. 200 p
Biolley HE (1921) L'aménagement des forêts par la méthode expérimentale et spécialement la méthode du contrôle. Ėditeurs Attinger frères Paris. $112 p$

FOREST EUROPE, UNECE, FAO (2011) State of Europe's Forests 2011. Status \& trends in Sustainable Forest Management in Europe. FOREST EUROPE Liaison Unit Oslo. ISBN 978-8292980-05-7. $337 \mathrm{p}$

FOREST EUROPE, UNECE, FAO (2010) National data reporting forms on pan-European indicators for sustainable forest management. Working paper. UNECE/FAO, Geneva

FOREST EUROPE, UNECE, FAO (2013) Joint FOREST EUROPE/ UNECE/FAO questionnaire on pan-European indicators for sustainable forest management. Working paper. UNECE/FAO, Geneva

Gurnaud A (1878) Cahier d'aménagement pour l'application de la méthode par contenance; Exposé sur la forêt des. Eperons, Paris, $160 \mathrm{p}$

Kuliešis A (1989) Medynų našumas ir jo panaudojimas. Forest stand yield and use (in Lithuanian). Agroleidykla, $141 \mathrm{p}$

Kuliešis A (1993) Lietuvos medynų prieaugio ir jo panaudojimo normatyvai. Forest yield models and tables in Lithuania (in Lithuanian). Kaunas, Girios Aidas. 383 p.

Kuliešis A, Saladis J, Kuliešis AA (2010) Development and productivity of young Scotch pine stands by regulating density. Balt For 16:235246

Kuliešis A, Tomter SM, Vidal C, Lanz A (2016) Estimates of stem wood increment in forest resources: comparison of different approaches in forest inventory; consequences for international reporting: case study European forests. Annals of Forest Science. Submitted

Oliver CD, Larson BC (1996) Forest stand dynamics. John Wiley \& Sons, Inc., New York, 544 p. ISBN 978-0-471-13833-4

Pretzsch H (2009) Forest dynamics, growth and yield. From measurement to model. Springer-Verlag, Berlin. doi:10.1007/978-3-54088307-4_13, $664 \mathrm{p}$

Тюрмер КФ (1891) Пятьдесят лет лесохозяйственной практики. Москва. Книжный магазин И. Дейбнера (in Russian). Tiurmer KF (1891) Fifty years of forestry practice. Moscow. Knižnij magazine I. Deibnera. 183 p

U.S. Department of Agriculture, Forest Service (2001) US Forest Facts and Historical Trends. FS-696. USDA Forest Service, Washington, $18 \mathrm{p}$

U.S. Department of Agriculture, Forest Service (2009) U.S. Forest Resource Facts and Historical Trends. USDA Forest Service, Washington, 62p

UNECE/FAO (2000) Forest resources of Europe, CIS, North America, Australia, Japan and New Zealand. Global forest resources assessment 2000. Main report. Geneva timber and forest study papers, No. 17. United Nations. New York and Geneva, 2000. ISBN 92-1$116735-3.445 \mathrm{p}$.

UNECE/FAO (2011) The European Forest Sector Outlook Study II 20102030. United Nations Publication Sales No E. 11.II.E. 14. 107 p.

Zöhrer F (1980) Forstinventur: Ein Leitfaden für Studium und Praxis. Pareys Studientexte 26, Verlag Paul Parey, Hamburg und Berlin. $207 \mathrm{p}$. 